\title{
SOME OBSERVATIONS ON BREEDING BROAD-WINGED HAWKS
}

\author{
E. OTTO HOHN, 11511-78 Avenue, Edmonton, Alberta. T6G 0N4
}

In the years 1982 to 1984 a pair of Broad-winged Hawks nested on or near our acreage $40 \mathrm{~km}$ east of Edmonton, Alberta. The area consists of pasture and poplar woods in roughly equal proportion and contains small ponds and a marsh. The hawks were not observed early in the season from 1982-1984, but first spring sightings in other years in this area, 22 April 1977 and 29 April 1979, suggest that they arrive in late April.

In 1982 a Broad-winged Hawk was flushed from the acreage entrance on 1 May. It was carrying a garter snake in its talons. On 18 May a Broad-winged Hawk was seen near an unfinished stick nest in a tall poplar on the acreage. By the 29th this nest was larger and a hawk, evidently incubating, was on the nest. Though the bird was not disturbed this nest was abandoned by 4 June. On 12 June an unfinished nest, decorated with a sprig of green leaves, again in a poplar, was found about $200 \mathrm{~m}$ from the first nest and a Broad-winged Hawk was soaring above this new nest. It was further enlarged up to 18 June but after that date no hawk was seen in its vicinity. This, like the first nest, had evidently been given up for no obvious reason. Single Broad-winged Hawks were seen in the area until early August. I was away for most of the next month and so cannot report whether or not they stayed into September.

In 1983 a Broad-winged Hawk was first seen in this area 7 May. Near noon, it was soaring at a height of about $180 \mathrm{~m}$ over a poplar wood and adjacent pasture, repeatedly swooping down and climbing and finally diving almost vertically with closed wings to disappear among the trees. Soon it flew up again accompanied by another hawk (presumably its mate) and the two engaged in similar though less spectacular soaring and swooping. This was evidently a courship flight such as I have only seen on this one occasion. As single Broad-wingeds were seen in the area after this date, a search was made for the nest, but it was not located until 5 June. A Broad-winged sailed out of an old nest well up in a Balsam Poplar when I tapped the tree trunk; it was in a wood separated from our acreage by a secondary road. Later visits showed that the bird was incubating. During five trips between 5 June and when young were first seen in the nest, the mate of the incubating hawk was seen only once, when it was perched about $10 \mathrm{~m}$ from the nest.

On 9 July the bird left the nest when I was still some $50 \mathrm{~m}$ away, instead of sitting tight as before; approaching closer, I could see the heads of two downy young. During the next four visits between 9 and 30 July there was always an adult hawk "on guard" in a tree at the edge of the nest wood. It would call continuously as long as I was in the area. On 30 July there was an adult on the nest which flew at my approach, returning to the nest only briefly (without delivering food) an hour later. On 4 August the two fully feathered young were perched a few $\mathrm{m}$ above the nest. Droppings, but no food remains, or pellets were found under the nest tree. In late August a sprig of green leaves on the first 1982 nest suggested that the hawks were possibly "working" on this nest for use in the 
following year. A Broad-winged Hawk was last seen in the area 11 September.

I did not visit the area until late May in 1984. On 26 May a Broad-winged Hawk flushed from the second nest the birds had used in 1982. On the next two visits the hawk, which was evidently incubating, left the nest when I was still at some distance. After 10 June it sat tight. It sat noticeably higher in the nest on the 29th and I took this to mean that the young had hatched, 35 days after the bird had first been found incubating. During all visits to 8 July an adult was on the nest, presumably brooding the young. Subsequently the adult hawk was on guard near but not on the nest; it called as long as I was in view but became silent 5-10 minutes after I had entered the blind set up some distance from the nest tree. Occasionally the adult on guard would fly just below the canopy of the trees following more or less my movements on the ground.

On 23 July remains, consisting of feathers, some of the intestine and the skull of a Northern Shoveler were found on the ground about $100 \mathrm{~m}$ from the nest tree. A few days later the corpse of a Mallard, from which most of the breast had been taken was found lying breastup on the shore of our dugout pond (somewhat nearer to the nest). As duck breast feathers were found beneath the nest tree about this time it would appear that these two ducks may have been killed by the Broad-winged Hawks. Other prey brought to the nest by the adult not on guard (which never stayed at the nest for more than 30 seconds) were mice and voles. Fur of these made up the pellets found beneath the nest tree where tail feathers of a robin were also found.

On 29 July one of the young was perched a few $m$ above the nest and on 2 August a flight of about $40 \mathrm{~m}$ was made. From then until the end of August, the young remained within 1-150 $\mathrm{m}$ of the

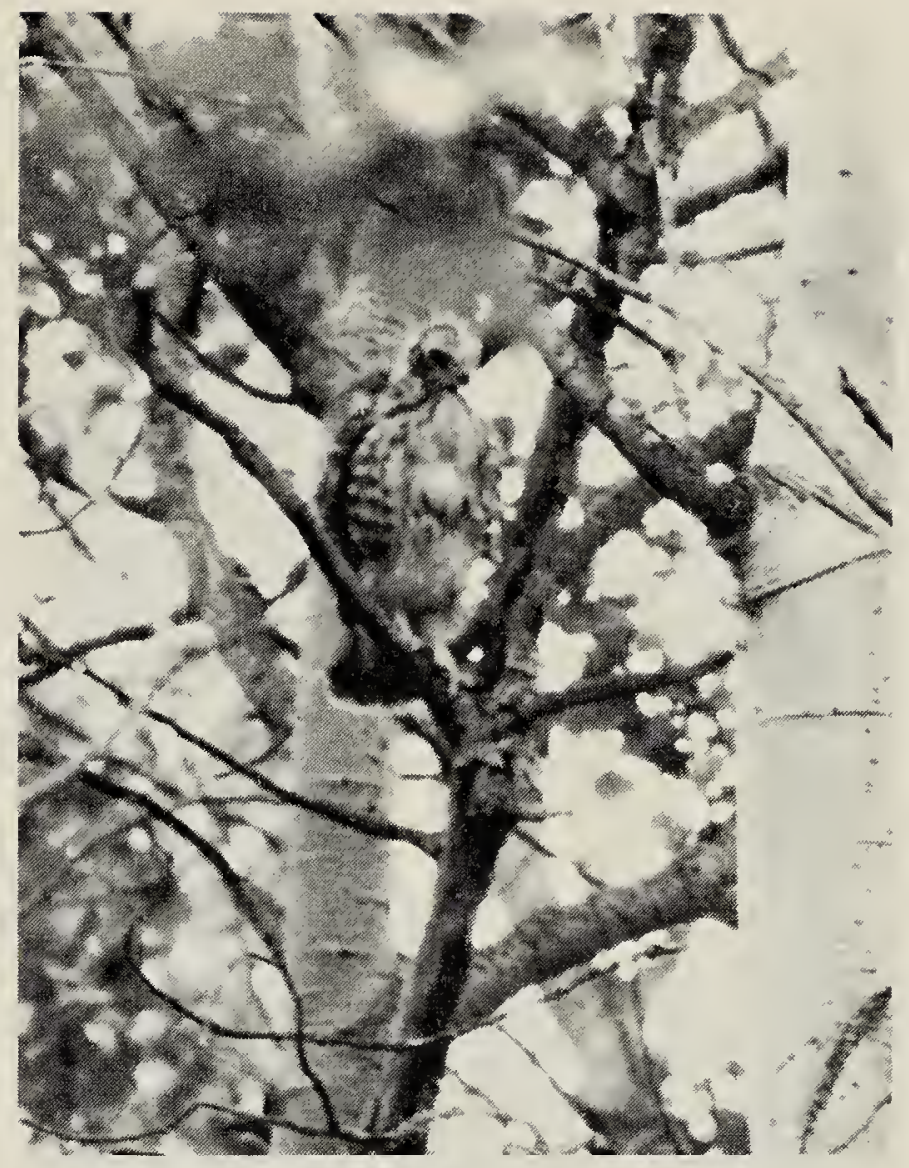

Young Broad-winged Hawk above nest, July 1984

E.O. Hohn

nest. The adult which was near called continuously while I was in view, but the young generally remained silent and were more difficult to locate. The adults accented the second syllable of their "pee-ee" call, while the young did not.

On 5 September 1984 about noon, first two, then three Broad-wingeds were soaring over the area to drift off to the southwest until out of sight. At least one of the three was a young of the year. Apparently the hawks left the area as a family (none were seen later that year) and probably migrated together.

\section{Discussion}

The findings reported above indicate that during the early phase of incubation the hawk generally left the nest on the approach of an observer but sat tight when incubation was advanced. This was evident in 1984; in 1983 incubation was evidently already advanced when the nest was found. The incubation period 


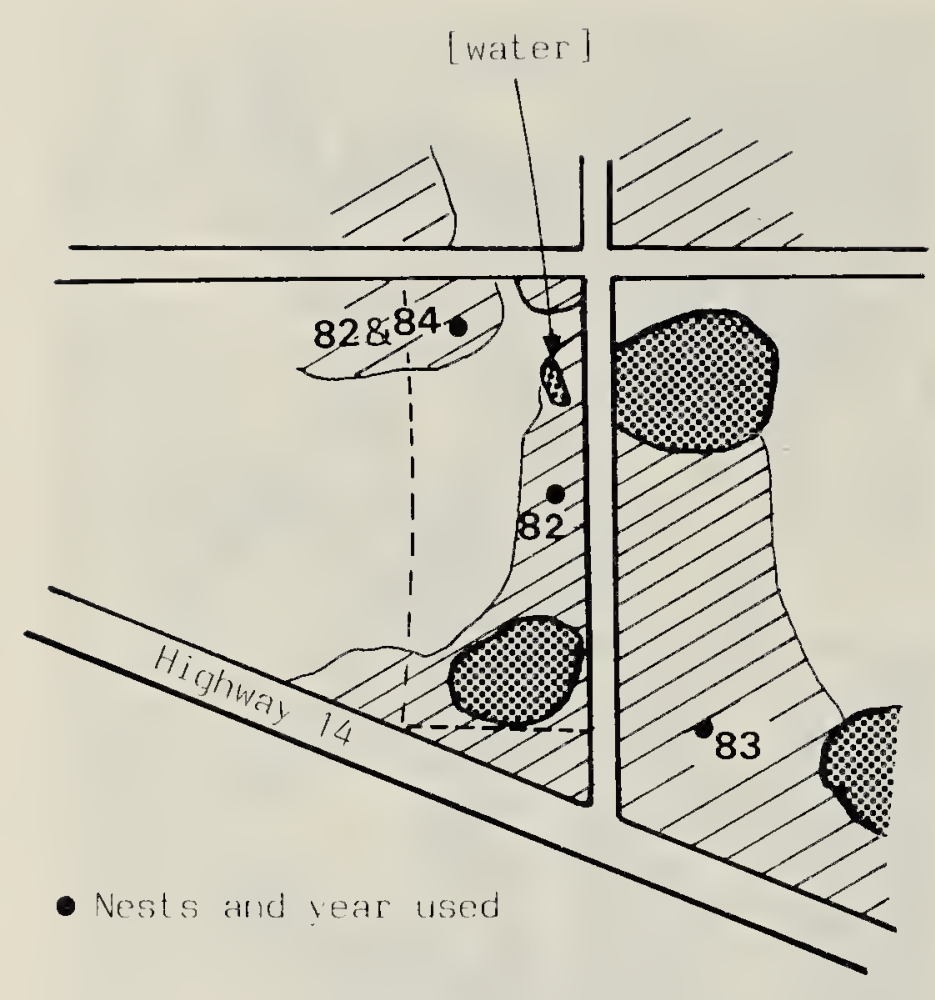

Woodlands

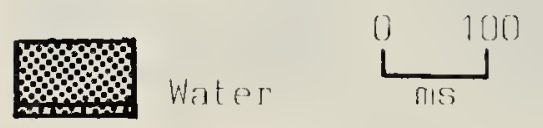

Sketch showing Broad-winged Hawk nests 1982-1984 in relation to woodland and water bodies

has been reported as "probably 28 days or longer." 1 The young had probably hatched somewhat before the 35 days apparent from the observations, but had not affected the adult's brooding posture while they were still very small.

After hatching, one adult (most probably the female) remained on guard near the nest and after the young had left the nest it remained near them. The second adult continued to do most or all of the hunting as it had done during incubation. The ducks apparently captured by this hawk are large prey; the largest previously recorded prey for this hawk appears to be the Ruffed Grouse. ${ }^{3}{ }^{4}$

The three nests varied in (estimated) height between 14 and $16 \mathrm{~m}$ and the tree diameter at breast height was between 23 and $41 \mathrm{~cm}$. These figures fall within the ranges of data presented by Rosenfeld. ${ }^{2}$
The two species used were the only ones of adequate size available in the area.

Studies in the Appalachians and in Wisconsin found that compared to a random sample of the available forest area, Broad-wingeds nested close to water and to forest clearings. ${ }^{5} 2$ The accompanying sketch map shows the location of the three nests in the study area, all near a forest edge and near standing water.

1 MATRAY, P.F. 1974. Broad-winged Hawk nesting and ecology. Auk 91(2):307-323.

2 ROSENFELD, R.N. 1984. Nesting biology of Broad-winged Hawks in Wisconsin. Raptor Research 18(1):6-9.

${ }^{3}$ ROSENFELD, R.N. and M.W. GRATSON. 1984. Food brought by Broad-winged Hawks to a Wisconsin nest. J. of Field Ornith. 55(2):246-247.

${ }^{4}$ RUSCH, D.H. and P.D. DOERR. 1972. Broadwinged Hawk nesting and food habits. Auk 89(1):139-145.

5 TITUS, K. and J.A MOSHER. 1981. Nest site habitat selection by woodland hawks in the central Appalachians. Auk 98(2):270-281.

\section{GREAT GRAY OWL BADGES}

The Blue Jay Bookshop, P.O. Box 1121, Regina, Saskatchewan S4P 3B4 has a supply of Great Gray Owl badges which they are selling to help raise money for the telemetry experiments, tracking of Great Gray Owls in Manitoba, supervised by Robert W. Nero. The badges are $\$ 2.75$ postpaid. $\$ 2.00$ from this goes towards the funding of the projects. 